\title{
Report from the first workshop of International Permafrost Association Action Group Rock glaciers inventories and kinematics
}

\author{
Răzvan POPESCU \\ University of Bucharest, Faculty of Geography \\ razvan.popescu@geo.unibuc.ro
}

\begin{abstract}
The recent initiative to standardize the mapping and monitoring of rock glaciers around the world resulted in the organization of the First Workshop of the Action Group Rock glaciers inventories and kinematics, in Evolene, Switzerland. The participants focused to discuss in detail and debate several issues to be introduced in a new version of a guidelines document regarding rock glaciers inventorying. This paper discusses the development of the field trips and working sessions of the workshop.
\end{abstract}

Keywords: rock glaciers, mountain permafrost, action group, workshop, International Permafrost Association

\section{INTRODUCTION}

Rock glaciers are permafrost containing landforms in mountain areas made of rocks and ice. They increased in importance in the last decades in the context of climate change because of two aspects: (1) in some countries with dryer climates where glaciers retreated significantly, rock glaciers become a more important water source for the summer river discharge (Rangecroft et al., 2015) and (2) in some areas it was documented an increment in rock glaciers velocities (Kääb et al., 2020) and an associated increase in sediment transfer rates that in several areas tend to threat the infrastructure. Also, rock glaciers even with a smaller content of ice in comparison to "true" glaciers, are considered more "resistant" to climate warming because of the insulating effect of debris mantle on top of permafrost (Jones et al., 2019).

In June 2018 the Action Group Rock glaciers and kinematics was founded under the auspices of International Permafrost Association (IPA) during the Fifth European Conference on Permafrost (EUCOP) held in Chamonix, France. The main goals of the group are (1) to standardize the rock glacier inventorying, (2) to prepare "products" for monitoring rock glaciers dynamics as a related parameter of permafrost ECV (essential climate variable) and (3) to create a worldwide rock glaciers data base and a web platform where data can be accessed.

On 23-27 September 2019 it took place the first workshop of the Rock glaciers inventories and kinematics Action Group in Evolène, in the canton of Valais, Switzerland. The workshop was dedicated to the first objective of the group, i.e. to define the guidelines for inventorying the rock glaciers. The importance of this issue resides from the nature of rock glaciers landforms, especially their limits that are sometimes very difficult to trace and thus exposed to subjectivity. In this respect, Francesco Brardinoni presented during the workshop a study that showed large inter-operator differences in identifying and delineating rock glaciers contours (Brardinoni et al., 2019). This is a major impediment for a global and consistent evaluation and monitoring of rock glacier phenomenon. 


\section{WORKSHOP FIELD TRIPS}

Three days of the workshop were dedicated to two field trips. The first one targeted the Perroc active landslide and the Tsarmine active rock glacier (Valais Alps, Arolla). The landforms are spectacular and have a rich field monitoring data base. For Tsarmine rock glacier (Fig. 1,2), in spite of the high activity rates (meters per year), most of the exposed boulders are covered with lichens indicating that rock fragments move mostly passive without rolling and that rock glaciers activity assessment only by lichen cover can be sometimes misleading.

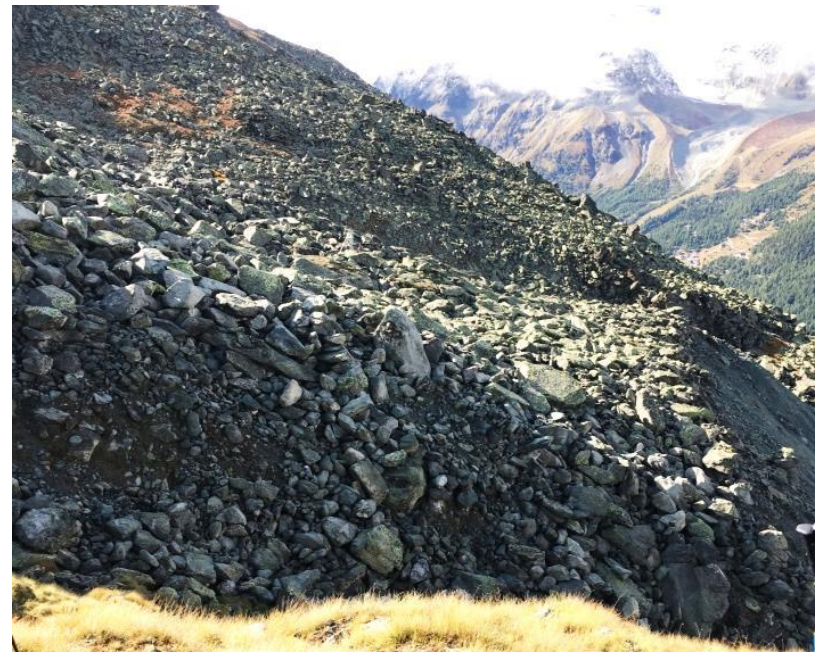

Figure 1 Tsarmine rock glacier lateral view. At the right its front intersects a gully and thus it is affected by backwards erosion

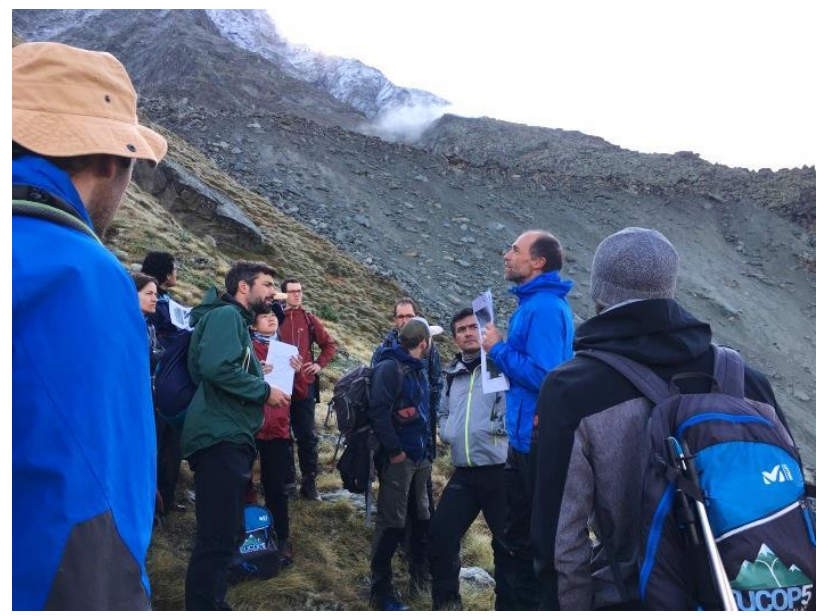

Figure 2 Discussions below the Tsarmine rock glacier front (in the background) led by Reynald Delaloye, chair of the action group
The second field trip was conducted in the Haut Vallon de Réchy area and Lona catchment (Fig. 3), it lasted two days (night spent on Becs-de-Bosson alpine hut at $2985 \mathrm{~m}$ asl) with the aim to visit several types of rock glaciers (from relict to active) and some particular case studies with rock glaciers in former interaction with glaciers. Becs-de-Bosson, Tsavolire and Lona rock glaciers were the main objectives. For Becs-de-Bosson we learned that in the upper part of the rock glacier there is no permafrost because it is the former area of a Little Ice Age (LIA) glacier and also that rock glacier lobes even very close to each other can move different. For the northern lobe only the inside area moves differently while the front is very slow; the southern lobe moves very fast across its entire surface and creates a periglacial push moraine (Fig. 4), a type of landform that is not often mentioned in the literature. Tsavolire is an active rock glacier moving of about a meter/year despite a positive mean multiannual ground surface temperature (https://www3.unifr.ch/geo/geomorphology/en/reso urces/study-sites/tsavolire.html). Lona is a landform that most participants classified as a typical rock glacier but it is in fact a vast push moraine created by the LIA glacier but with typical rock glacier morphology. Permafrost is present only in the margins of the former glacier but downslope movement characterizes all the area of the landform. Another site of observation was dedicated to a complex of relict rock glaciers/moraines (Fig. 5). Several exercises on mapping rock glaciers and discussions about origin, relation to moraines and rock glacier activity were conducted in the field.

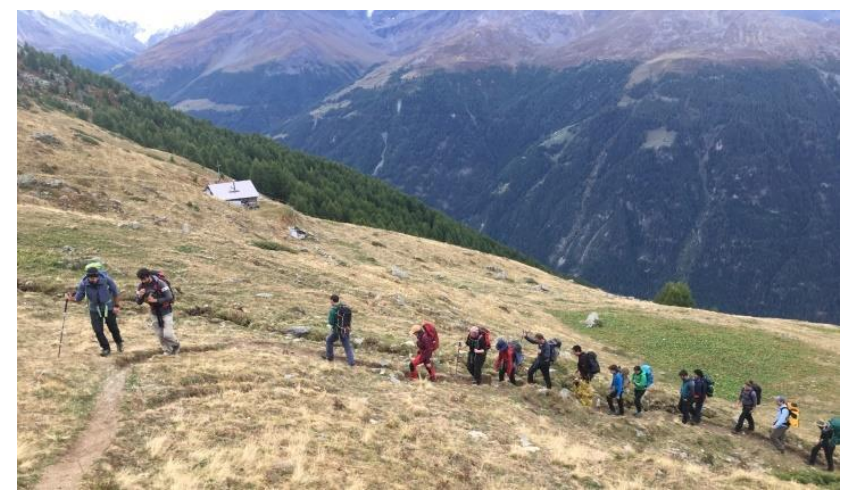

Figure 3 Workshop participants in the Haut Vallon de Réchy 


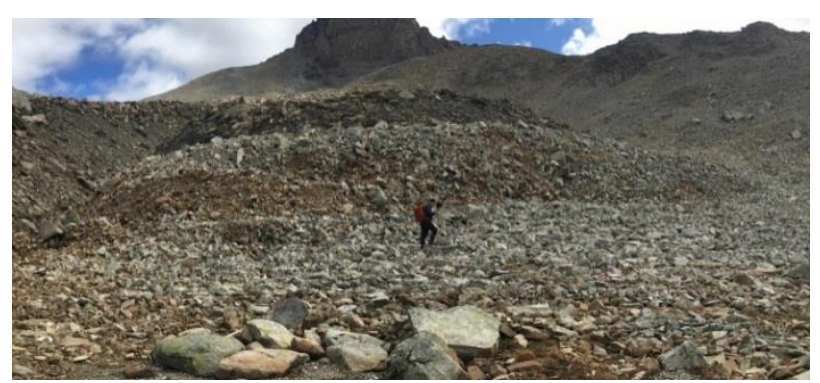

Figure 4 Periglacial push moraine seen from below created by the advancing Becs-de-Bosson southern rock glacier lobe

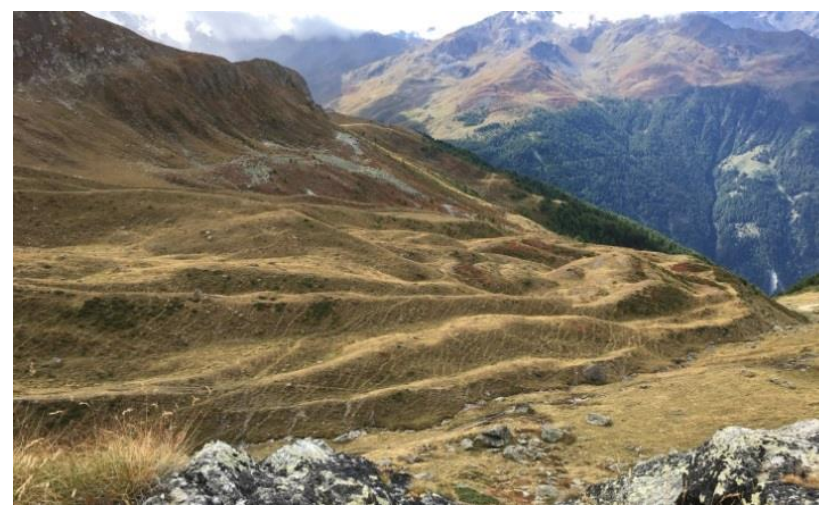

Figure 5 Landform complex (moraines or relict rock glacier) west of Lona Pass

\section{WORKSHOP SESSIONS}

The field trips were followed by common sessions, presentations and work sessions in which there were presented and debated most of the details that have to be taken into account when performing a rock glacier inventory. For the work sessions, the group of participants was split into several small groups that discussed several topics concerning the following subjects:

- technical definition of rock glaciers;

- rock glaciers units;

- connection to the upslope unit;

- definition to the rock glaciers boundary;

- differentiation between rock glaciers and debris covered glaciers;

- rock glaciers activity;

- inventorying strategy;

- practical concepts for assessing activity;

- guidebook: structure and content;

- implementation: how to proceed.

I participated in the rock glaciers units (1) and definition to the rock glaciers boundary groups (2).
Each session ended with a written document in which several issues were addressed and several topics were formulated in order to be included after a revision in a new version (3.0) of the document "Towards standard guidelines for inventorying rock glaciers" (the document can be seen here: https://www3.unifr.ch/geo/geomorphology/en/resea res/ipa-action-group-rock-glacier/).

During the common sessions several presentations regarding rock glaciers were held:

- Risks and Opportunities of a Rock Glacier Inventory, by Lukas Arenson;

- Evaluating sources of uncertainty and variability in rock glacier inventories, by Francesco Brardinoni;

- The (Rock) Glacier Inventory of Argentina, by Lukas Ruiz;

- Frozen debris lobes from Alaska, by Margaret Darrow (included also an artistic moment).

\section{CONCLUSIONS}

There was a major opportunity to be together with many specialists in rock glaciers and mountain permafrost from around the world. According to the organizers, there were a total of 42 participants from 14 countries and 4 continents! Also, there was a great opportunity to visit in the field several types of rock glaciers including active ones and to be able to take part at on site discussions about mapping, formation, evolution, recent glacial-periglacial interactions and monitoring rock glaciers.

The results of this action group will solve a major problem in the scientific community in what concerns the reducing of uncertainties and subjectivity in rock glacier inventories and the necessary steps to use the rock glaciers and mountain permafrost as a proxy for climate variability monitoring.

\section{ACKNOWLEDGEMENTS}

I thank the University of Bucharest and Faculty of Geography for providing the travel grant that made my participation possible. 


\section{REFERENCES}

Brardinoni, F., Scotti, R., Sailer, R., Mair, V. (2019). Evaluating sources of uncertainty and variability in rock glacier inventories. Earth Surface Processes and Landforms, 44(12), 2450-2466.

Jones, D. B., Harrison, S., Anderson, K., Whalley, W. B. (2019). Rock glaciers and mountain hydrology: A review. Earth-science reviews, 193, 66-90.
Kääb, A., Strozzi, T., Bolch, T., Caduff, R., Trefall, H., Stoffel, M., \& Kokarev, A. (2020). Inventory, motion and acceleration of rock glaciers in Ile Alatau and Kungöy Ala-Too, northern Tien Shan, since the 1950s. The Cryosphere Discussions, 1-37.

Rangecroft, S., Harrison, S., Anderson, K. (2015). Rock glaciers as water stores in the Bolivian Andes: an assessment of their hydrological importance. Arctic, Antarctic, and Alpine Research, 47(1), 89-98. 